\title{
University students' constructions of 'flourishing' in British higher education: An inductive content analysis
}

\author{
Nesrin Gokcen • Kate Hefferon • Elizabeth Attree
}

\begin{abstract}
The potential to flourish as a student has emerged as a topic of debate amid the current period of economic transition in British Higher Education (HE). The present study sought to explore the concept of 'flourishing' as it is constructed by students in British HE. An open-ended questionnaire was distributed to 222 students across two post-1992 (former polytechnic) British universities to elicit written qualitative data on their understandings of 'flourishing' and 'flourishing at university', and of their characterisations of 'flourishing' and 'non-flourishing' students. Data was content analysed using an inductive approach. Prominent categories emerging from the data sets constructed 'flourishing' primarily as self-actualisation (personal growth, potential realisation) and success. However, engagement (both academic and social) emerged as a significant facet of 'flourishing at university'. The 'flourishing student' was characterised as academically and socially engaged, committed to learning, and oriented towards personal growth. Conversely, the 'non-flourishing' student emerged as having a general sense of lacking, a disengaged attitude towards academic work, and a lazy/withdrawn outlook. Results provide inductively derived support for four components of Wellbeing Theory - positive emotions, engagement, relationships, and achievement (Seligman, 2011) and allow generic understandings of 'flourishing' to be contextualised within a HE setting. Further implications of the study and suggestions for future research are discussed with regard to the findings.
\end{abstract}

Keywords: flourishing, higher education, wellbeing, university students, content analysis

\section{Introduction}

To 'flourish' is defined by the Concise Oxford Dictionary (1964) as to "grow vigorously; thrive, prosper, be successful; be in one's prime" (p. 467). The word derives from the Latin flor, meaning flower, coming from the Proto-Indo-European *bhlo - to bloom. Metaphorically, too, flourishing can be likened to the blooming of flowers: the phenomenon signifies fulfilment of an organism's inherent nature, cultivating its own wellbeing and also that of others in an ecological or social system.

Colloquial use of the term 'flourishing' tends to centre on ideas of realising one's potential (spiritually, developmentally, economically, etc.), succeeding, achieving, or making some significant contribution to society. One of the first appearances of flourishing in philosophical thought was in Aristotle's virtue ethics, which focused on collective flourishing as an ideal state of society in which citizens fulfil their inherent nature to act virtuously (Aristotle, 350 BC/2000; Hill, 1999). The idea of flourishing as a collective phenomenon has also been evident in Marxist philosophy, in which a reorganisation of society is called for that better facilitates citizens' 
virtuous conduct, leading to widespread flourishing in society (Leopold, 2007; Marx, 1959/1988). More recently, there has been a change of focus from collective to individual flourishing, and from studying flourishing philosophically to empirically (Seligman, 1999). Positive psychological perspectives on flourishing have generally moved from happiness- or life satisfaction-oriented theories (e.g. Seligman, 2002) to models of total wellbeing or global flourishing (Forgeard, Jayawickreme, Kern, \& Seligman, 2011; Seligman, 2011).

Earlier approaches to wellbeing have focused on psychological need satisfaction as a key requirement for positive human functioning or psychological health (e.g. Deci \& Ryan, 1985; Ryff, 1989). Later accounts have assimilated these approaches into positive psychological understandings of flourishing or wellbeing (e.g. Deci \& Ryan, 2008a, 2008b; Ryan, Huta, \& Deci, 2008; Ryff \& Singer, 2006). Mental health perspectives on flourishing (particularly Keyes, 2002) assert that flourishing is a form of positive mental health distinct from the mere absence of mental illness, with the majority of individuals falling somewhere in the middle of the flourishing-languishing mental health continuum (Keyes, 2005, 2006, 2007a, 2007b). Recent cross-national studies of European populations have confirmed that flourishing is a construct distinct from subjective wellbeing, both with regard to its multidimensionality and to the generally low rate of co-occurrence of flourishing and indicators of subjective wellbeing such as life satisfaction (Huppert \& So, 2009, 2011). More recently, global wellbeing perspectives on flourishing have built on both need satisfaction and mental health approaches to produce models of complete optimal functioning of the individual (Seligman, 2011; Vittersø, 2009). Wellbeing Theory is perhaps comprehensive in bringing together the current known facets of flourishing in its 'PERMA' model, which incorporates positive emotions, engagement, relationships, meaning, and achievement (Seligman, 2011).

Existing approaches to flourishing, particularly within positive psychology, tend to adopt a consistently positivist epistemology (Bauer \& Perciful, 2009). Although this has enabled scientific understandings of flourishing to be developed, it does not enable subjective understandings of flourishing to be acknowledged or incorporated into existing theories of wellbeing. Consequently, little is known about the ways flourishing may be conceptualised by individuals. It is well documented (e.g. Krippendorf, 2004; Miller \& Hoogstra, 1992; Vygotsky, 1986) that individuals' use of language and vocabulary in relation to concepts is essentially a manifestation of their interpretations of sociocultural constructions of such concepts. Given this, it cannot initially be assumed that empirically derived theories of wellbeing necessarily account for the experience and sociocultural construction of flourishing in a comprehensive sense.

Research to date has not addressed flourishing in specific life domains, perhaps with the exceptions of work (Fredrickson, 2003; Losada, 1999; Losada \& Heaphy, 2004) and marriage (Gottman, 1994), with the majority focusing on global flourishing (Catalino \& Fredrickson 2011; Diener, personal communication, 2 November 2010; Huppert \& So, 2011; Seligman, 2011). Higher Education presents a relevant domain in which flourishing merits further research, particularly in the context of ongoing reductions in public funding in a variety of academic subject areas and an increased focus on 'value for money' in HE (Browne et al., 2010). Such economic change appears to have come with a rise in consumerist attitudes in students as well documented in North America (Delucchi \& Korgen, 2002; Fairchild et al., 2007) and, to a lesser extent, the United Kingdom (Kaye, Bickle, \& Birtwistle, 2006; Naidoo \& Jamieson, 2005). Development of an inductively derived understanding of 'flourishing' specific to the sub- 
population of individuals who are learners in HE will conceivably make a number of contributions to both educational practice and positive psychology. Firstly, positive psychological perspectives on flourishing may be broadened by lay conceptualisations of the construct, allowing a more comprehensive, socially grounded understanding of students' potential to flourish. Secondly, by understanding students' conceptualisations of 'flourishing' and 'non-flourishing' students, recommendations may be developed as to how educationalists can contribute to the flourishing of their students. Finally, an inductively derived understanding of flourishing may be used to support future research investigating the relationships between a range of contemporary issues in HE (e.g. student consumerism, instrumental learning) and students' potential to flourish.

The present study employed an inductive content analysis to develop a conceptualisation of flourishing from the perspective of students in British HE, where reductions in public funding and increases in tuition fees in 2010-12 have initiated debate about how students may flourish in the context of significant economic change. Specifically, we adopted three research questions:

1) How do students in British HE understand 'flourishing'?

2) How do they understand 'flourishing at university'?

3) How do they characterise 'flourishing' and 'non-flourishing' students?

\section{Method}

\subsection{Participants}

We used a sample of 222 students enrolled on a variety of undergraduate and postgraduate courses (including psychology, engineering, computing, management and sports therapy) across three campuses of two post-1992 (former polytechnic) British universities in the southeast of the UK. The students (95 males, 92 females, 35 data withheld) were recruited in lectures and seminars through personal affiliation with lecturers. Their ages ranged from 18 to 52 (213 valid cases, $M=25.9, S D=7.77)$. Although students were not asked to identify their ethnic background, they were recruited from institutions known to be inclusive of ethnically diverse student populations (Business in the Community, 2010). Of the 185 students who reported their mode of study, $156(84.3 \%)$ identified themselves as studying full time.

\subsection{Questionnaire format}

A one-page questionnaire was developed for the purpose of data collection from students (see Appendix A). The questionnaire included two open-ended questions (What does 'flourishing' mean? What does it mean to flourish at university?) and two prompts (Please list the characteristics of a student who is flourishing at university / Please list the characteristics of a student who is not flourishing at university). Thus, the questionnaire elicited four separate data sets; one in response to each item. Demographic data was entered at the top of the questionnaire. ${ }^{1}$

\subsection{Coding strategy}

Data sets obtained in response to each questionnaire item were analysed separately. In all data sets, a single inductive coding strategy was used as opposed to traditional deductive analysis.

\footnotetext{
${ }^{1}$ The raw data can be seen in the supplementary file for this article.
} 
First, comments in each data set were read through by the first author to gain insight into the range of keywords used. 'Keywords' were defined as any word or phrase used to convey a substantial idea within a comment (Hsieh \& Shannon, 2005). However, in order for the analysis to remain grounded in the data, this meant virtually all words were taken into account, leaving only prepositions (e.g. in, on) and some pronouns (e.g. he, she) excluded.

All keywords were counted. Individual keyword frequencies ranged from one to 148 across all questionnaire sections. Keywords were then arranged into clusters within their respective data sets based upon consideration of two indicators: semantic and contextual (see Figure 1). Semantic indicators referred to the popular or colloquial meanings of keywords. Contextual indicators referred to the social, cultural, or political context(s) in which keywords were used in individual comments. In combination, consideration of semantic and contextual indicators allowed all keywords to be grouped into meaningful clusters. These constituted our 'concepts'.

Figure 1. Exemplification of the coding strategy with the keyword 'grow

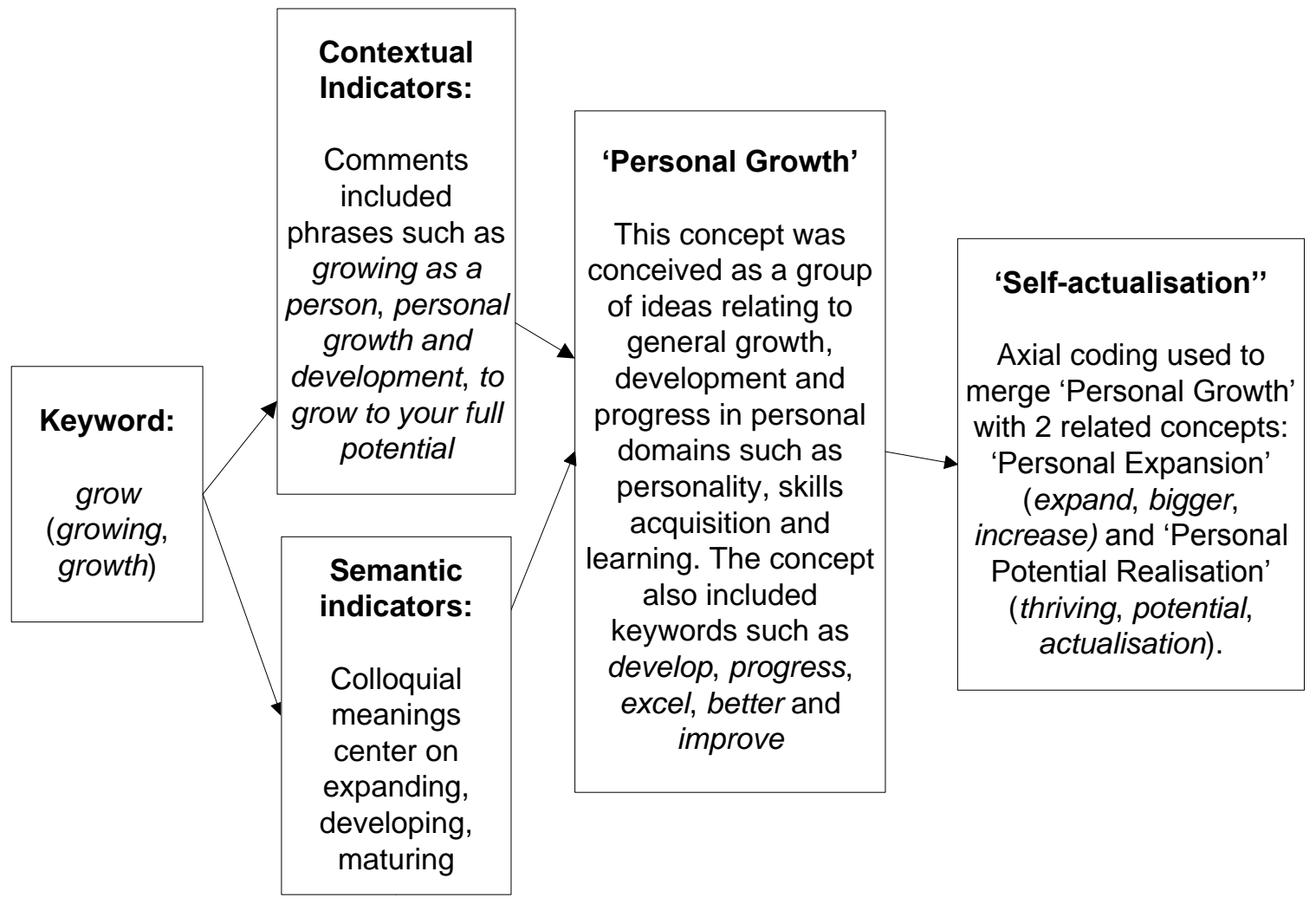

Following this, a form of axial coding was employed in which concepts were coded together to form over-arching categories. The 'coding together' of concepts was once again based upon consideration of semantic and contextual similarity between concepts (Krippendorf, 2004; see Figure 1). Reliability of the coding procedure was confirmed in an independent audit conducted by the second author.

\section{Results}

Data in our sample's understandings of 'flourishing' generally centred on ideas of selfactualisation and success, with secondary categories focusing on the individual/personal nature of flourishing and on positive affect. Engagement with academic work and with the social 
learning environment was a significant category emerging from the data on 'flourishing at university', although ideas of success and wellbeing were also prominent. The 'flourishing' student was generally constructed as behaviourally and attitudinally engaged, committed to learning and as having vitality and an orientation towards personal growth, while the "nonflourishing' student was portrayed as having a general sense of 'lacking', and as being disengaged, lazy, withdrawn, struggling, and unwilling to strive for progress. An overview of the main categories emerging from our data is presented in Figure 2.

Figure 2. Overview of categories emerging from inductive content analysis of 4 written data sets elicited from 222 students

Self-actualisation

Note: Prominent categories (those mentioned by $50 \%$ or more of our sample) are given in bold.

Several contradictions also emerged from our data which concerned an introversionextraversion paradox in flourishing, individual vs. collective flourishing, and whether an individual's flourishing is determined by intrinsic or extrinsic parameters. 


\subsection{Data Set 1: 'What does 'flourishing' mean?'}

\subsubsection{Self-actualisation}

The category of self-actualisation emerged from references to personal expansion, growth, and potential realisation (summarised in Table 1). These were mentioned by $80 \%$ of the sample (219 valid comments). Thirteen per cent of comments referred to increases in size (keywords included increase, expand, bigger) in the context of personal expansion of skills, knowledge, or life view. Relating to this, $69 \%$ of comments mentioned some form of personal growth with a specific emphasis on growth in quality rather than size (e.g. development, progress, better). Finally, $23 \%$ of comments referred to personal potential realisation, encompassing ideas about striving to reach personal potential, thriving, and blossoming (e.g. blooming, blossoming, prospering).

Table 1. Concept and category codebook for Data Set 1

\begin{tabular}{|c|c|c|c|}
\hline Category & Overview & $\begin{array}{l}\text { Keyword } \\
\text { examples }\end{array}$ & Text examples \\
\hline $\begin{array}{l}\text { 3.1.1 Self- } \\
\text { actualisation }\end{array}$ & & $\begin{array}{l}\text { expand } \\
\text { increase } \\
\text { greater }\end{array}$ & $\begin{array}{l}\text { "To allow for an expansion of knowledge and } \\
\text { experience." (P. 243) } \\
\text { "To grow into something bigger and better." (P. }\end{array}$ \\
\hline $\begin{array}{l}\text { Personal } \\
\text { expansion }\end{array}$ & $\begin{array}{l}\text { Mentions of increases in size } \\
\text { (expansion). }\end{array}$ & $\begin{array}{l}\text { improve } \\
\text { develop } \\
\text { grow }\end{array}$ & $\begin{array}{l}\text { 214) } \\
\text { "Grow and develop in a healthy way." (P. 192). } \\
\text { "It is a term associated with growth and getting }\end{array}$ \\
\hline Personal growth & $\begin{array}{l}\text { Mentions of getting better, } \\
\text { developing or improving } \\
\text { (growth). }\end{array}$ & $\begin{array}{l}\text { progress } \\
\text { excel } \\
\text { prosper } \\
\text { thriving }\end{array}$ & $\begin{array}{l}\text { better...” (P. 157) } \\
\text { “Growing, extending, to thrive.” (P. 76). } \\
\text { “...something growing, flowering, blooming." } \\
\text { (P. 46) }\end{array}$ \\
\hline $\begin{array}{l}\text { Personal potential } \\
\text { realisation }\end{array}$ & $\begin{array}{l}\text { Mentions of reaching or } \\
\text { striving for some higher } \\
\text { potential (potential } \\
\text { realisation). }\end{array}$ & $\begin{array}{l}\text { potential } \\
\text { blooming }\end{array}$ & $\begin{array}{l}\text { "Grow and develop...in every sense possible." } \\
\text { (P. 38) }\end{array}$ \\
\hline 3.1.2 Success & & $\begin{array}{l}\text { success } \\
\text { ambitious }\end{array}$ & $\begin{array}{l}\text { "To do well in something." (P. 5) } \\
\text { "...doing well... and achieving." (P. 10) }\end{array}$ \\
\hline Ambition & $\begin{array}{l}\text { Mentions of being ambitious } \\
\text { or successful, mastering } \\
\text { skills, and hitting targets or } \\
\text { aims. }\end{array}$ & $\begin{array}{l}\text { achieve } \\
\text { goals } \\
\text { skill } \\
\text { ability } \\
\text { well }\end{array}$ & $\begin{array}{l}\text { "...to achieve and meet goals." (P. 39) } \\
\text { "The most success that you could have." (P. 62) } \\
\text { “....in university flourishing would mean getting } \\
\text { the optimum skills required under course of } \\
\text { study." (P. 82) }\end{array}$ \\
\hline Doing well & $\begin{array}{l}\text { Mentions of 'doing well' or } \\
\text { being good/the best at } \\
\text { something. }\end{array}$ & $\begin{array}{l}\text { best } \\
\text { education } \\
\text { course } \\
\text { grades }\end{array}$ & $\begin{array}{l}\text { "Means to "do well", "succeed"..." (P. 92) } \\
\text { “...complete all coursework and exams and pass } \\
\text { with good grades." (P. 143) }\end{array}$ \\
\hline Academic success & $\begin{array}{l}\text { Mentions of success in } \\
\text { academic settings, including } \\
\text { passing exams or doing well } \\
\text { in assignments. Mentions of } \\
\text { successful learning or } \\
\text { knowledge acquisition. }\end{array}$ & $\begin{array}{l}\text { understand } \\
\text { learning } \\
\text { knowledge }\end{array}$ & \\
\hline
\end{tabular}


Table 1. Concept and category codebook for Data Set 1 (Cont.)

\begin{tabular}{|c|c|c|c|}
\hline Category & Overview & $\begin{array}{l}\text { Keyword } \\
\text { examples }\end{array}$ & Text examples \\
\hline $\begin{array}{l}3.1 .3 \\
\text { Flourishing as a } \\
\text { personal or } \\
\text { individual } \\
\text { phenomenon }\end{array}$ & $\begin{array}{l}\text { Mentions of flourishing as an } \\
\text { individual rather than as a } \\
\text { group, community, or } \\
\text { society. Mentions of, or } \\
\text { emphasis on, flourishing as } \\
\text { an intrinsic or personal state } \\
\text { or phenomenon which } \\
\text { occurs within an individual. }\end{array}$ & $\begin{array}{l}\text { person } \\
\text { personal } \\
\text { individual } \\
\text { your } \\
\text { yourself } \\
\text { one } \\
\text { oneself } \\
\text { someone }\end{array}$ & $\begin{array}{l}\text { "Gaining...what the individual } \\
\text { wants/desire[s]..." (P. 4) } \\
\text { "Expanding personal knowledge for personal } \\
\text { growth." (P. 7) } \\
\text { "...the state that the individual is fulfilling their } \\
\text { potential...growing as an individual." (P. 16) } \\
\text { "Growing in your knowledge of the world and } \\
\text { your personality; knowing more about } \\
\text { yourself..." (P. 25) } \\
\text { "To better yourself through self development } \\
\text { and to progress into a 'new you'..." (P. 222) }\end{array}$ \\
\hline $\begin{array}{l}\text { 3.1.4 Positive } \\
\text { affect }\end{array}$ & $\begin{array}{l}\text { Mentions of general positive } \\
\text { affect, including happiness, } \\
\text { enjoyment, etc. Mentions of } \\
\text { hedonic wellbeing. Mentions } \\
\text { of openness or vitality in an } \\
\text { emotional context. }\end{array}$ & $\begin{array}{l}\text { fulfilment } \\
\text { happy } \\
\text { satisfaction } \\
\text { caring } \\
\text { lively } \\
\text { enjoy } \\
\text { feel } \\
\text { outgoing } \\
\text { enthusiasm } \\
\text { open }\end{array}$ & $\begin{array}{l}\text { "...being happy." (P. 8) } \\
\text { "To pursue happiness." (P. 17) } \\
\text { “...alive...generally happy and settles in what } \\
\text { one is doing...be open to challenges." (P. 233) } \\
\text { "To make the most of your fulfilment during } \\
\text { times of happiness." (P. 88) }\end{array}$ \\
\hline
\end{tabular}

\subsubsection{Success}

We identified $64 \%$ (219 valid comments) of comments making some reference to popular or conventional ideas about success, such as achieving goals or doing well in activities (see Table 1). This category emerged from three concepts relating to ambition, doing well, and academic success. Thirty-eight per cent of comments referred to ideas about ambition (e.g. challenge, goals, production, skill) both in education and in general life. Twenty-three per cent made reference to doing well. This was distinguished from the first concept, ambition, by its focus on successful outcomes (doing an activity well, meeting expectations, being above average) rather than behaviours that lead to such outcomes (e.g. acquiring skills, overcoming adversity). Academic success was mentioned by $22 \%$ of the sample. This concept included references to academia (education, course, grades) and achieving academic success. The concept also included keywords such as knowledge, insight and understanding which were used to characterise flourishing as intrinsic or personal learning.

\subsubsection{A personal or individual phenomenon}

Thirty-five per cent of comments related to flourishing as a personal or individual phenomenon (219 valid comments; see Table 1). Given the theoretical distinctions between collective flourishing (as conceptualised in moral philosophical and Marxist perspectives, Leopold, 2007) and individual flourishing ('individualist' perspectives focusing on the flourishing of individuals rather than communities, e.g. Diener et al., 2010), we classified references to personal or individual flourishing as a separate category. This included references to the 'individual' or 'personal' success or development which highlighted flourishing as occurring within an individual rather than among individuals. The category also included pronouns (you, 
yourself, one, someone) which were used in contexts highlighting an 'individual' nature of flourishing.

\subsubsection{Flourishing as positive affect}

The category of positive affect emerged from a range of comments mentioning happiness, satisfaction, enjoyment, and other keywords denoting hedonic wellbeing ( 219 valid comments; Table 1). Twenty-three per cent of comments identified positive affect as either wholly or partially constituting flourishing. Keywords in this category related to positive emotions (happy, content, satisfied) as well as the personal experience of emotions (sense, feel, affected). In addition to these, some keywords also related to positive moods (lively, creative, enjoy), used in contexts that indicated short-term moods rather than longer-term emotional experiences such as life satisfaction.

\subsection{Data Set 2: 'What does it mean to flourish at university?'}

\subsubsection{Academic and social engagement}

The category of academic and social engagement emerged from a range of comments relating to being successful and learning at university, and being socially engaged with others in the university environment (see Table 2). These were mentioned by the majority of the sample (92\%; 217 valid comments). We identified three concepts within this category: 'academic success', 'learning', and 'social engagement'. Academic success was mentioned by two thirds $(67 \%)$ of students, including general success in one's chosen course or subject of study, achieving good grades, and doing well in exams and other forms of assessments. Fifty-three per cent of comments mentioned learning as a form of flourishing. Our 'learning' concept drew on keywords that related to acquisition of knowledge and understanding that leads to positive personal development rather than extrinsic success such as good grades. A third concept in this category was social engagement (mentioned in $28 \%$ of comments). This included ideas relating to social involvement with others at university (staff, friends, interact, converse) and participation in social events (activities, meeting).

\subsubsection{Success}

This category related to popular or conventional ideas about success such as goal achievement, summarised in Table 2. Two thirds (66\%) of comments referred to success (217 valid comments). We developed this category from a group of comments that mentioned success in contexts similar to our 'Success' category (3.1.2) in Data Set 1. The category also included two concepts previously identified - 'ambition' and 'doing well'. Thirty-six per cent of comments mentioned 'ambition' (keywords included challenge, skill, goals, success) often without any explicit reference to academia. Forty-two per cent of comments also made references to 'doing well' (well, good, best, top) in the context of 'wellness' or the process of doing well in life domains such as education.

\subsubsection{Wellbeing}

We identified $56 \%$ of comments that made reference to wellbeing ( 217 valid comments). This category was composed of two concepts (Table 2). A major concept, 'personal growth' (mentioned in $44 \%$ of comments), was similar to the 'self-actualisation' concept (1.1) identified 
in Data Set 1 (keywords included grow, potential, progress). Fifteen per cent of comments referred to a second concept, 'enjoyment'. This concept emerged from a group of keywords relating to enjoyment of life, engagement or general enthusiasm (e.g. happy, enjoy, interest, fulfilment).

Table 2. Concept and category codebook for Data Set 2

\begin{tabular}{|c|c|c|c|}
\hline Category & Overview & $\begin{array}{l}\text { Keyword } \\
\text { examples }\end{array}$ & Text examples \\
\hline $\begin{array}{l}\text { 3.2.1 Academic and } \\
\text { social engagement } \\
\text { Academic success }\end{array}$ & $\begin{array}{l}\text { Mentions of being successful } \\
\text { at university by meeting } \\
\text { extrinsic criteria (e.g. passing } \\
\text { exams, etc.). } \\
\text { Mentions of personal learning } \\
\text { and/or self development by } \\
\text { gaining knowledge. } \\
\text { Mentions of being socially } \\
\text { engaged with university life. }\end{array}$ & $\begin{array}{l}\text { grades } \\
\text { exam } \\
\text { assignment } \\
\text { course } \\
\text { career } \\
\text { education } \\
\text { learning } \\
\text { knowledge } \\
\text { work } \\
\text { social } \\
\text { friends } \\
\text { interact } \\
\text { staff } \\
\text { activities }\end{array}$ & $\begin{array}{l}\text { “...having a good social network of uni } \\
\text { friends." (P. 4) } \\
\text { "Constantly bettering...grades...being } \\
\text { engaged... with your course, interested } \\
\text { in what you are doing - to the point } \\
\text { that you feel uplifted/enlightened when } \\
\text { you study." (P. 8) } \\
\text { “...to understand the topic you are } \\
\text { studying." (P. 11) } \\
\text { “To get good grades and work hard, } \\
\text { someone who asks questions and gets } \\
\text { involved in different activities." (P. 50) } \\
\text { “...obtaining good grades at the } \\
\text { university. Also means...personal } \\
\text { interaction skills..." (P. 94) } \\
\text { "Learn at a higher level." (P. 137) }\end{array}$ \\
\hline $\begin{array}{l}\text { 3.2.2 Success } \\
\text { Ambition }\end{array}$ & $\begin{array}{l}\text { Mentions of conventional } \\
\text { success, often without explicit } \\
\text { reference to academia. } \\
\text { Mentions of being ambitious } \\
\text { (taking challenges, hitting } \\
\text { targets, etc.). Mentions of } \\
\text { doing well or being good at } \\
\text { something. }\end{array}$ & $\begin{array}{l}\text { skill } \\
\text { goal } \\
\text { success } \\
\text { challenge } \\
\text { opportunity } \\
\text { well } \\
\text { best } \\
\text { top } \\
\text { good } \\
\text { expectations }\end{array}$ & $\begin{array}{l}\text { "To be able to develop skill set required } \\
\text { to function successfully..." (P. 23) } \\
\text { "To do well..." (P. 30) } \\
\text { "Do well and perform above the level } \\
\text { you expect or are expected." (P. 99) } \\
\text { "It means to use the opportunity that } \\
\text { you have..." (P. 120) } \\
\text { "Successful or active." (P. 131) } \\
\text { "To be a successful student..." (P. 153) }\end{array}$ \\
\hline $\begin{array}{l}\text { 3.2.3 Wellbeing } \\
\text { Personal growth }\end{array}$ & $\begin{array}{l}\text { Mentions of personal growth, } \\
\text { progress, or realisation of } \\
\text { personal potential. } \\
\text { Mentions of enjoyment and } \\
\text { feeling good. }\end{array}$ & $\begin{array}{l}\text { grow } \\
\text { progress } \\
\text { potential } \\
\text { improve } \\
\text { better } \\
\text { excel } \\
\text { enjoy } \\
\text { happy } \\
\text { enthusiasm } \\
\text { feel } \\
\text { positive } \\
\text { interest } \\
\text { confidence }\end{array}$ & $\begin{array}{l}\text { "...to be happy and satisfied..." (P. 250) } \\
\text { "...enjoying experience..." (P. 1) } \\
\text { "To enjoy your studies." (P. 2) } \\
\text { "Ability to progress through your } \\
\text { coursework..." (P. 148) } \\
\text { "...to be progressing..." (P. 156) } \\
\text { "Become better and better." (P. 164) } \\
\text { "To develop as a student and a } \\
\text { researcher..." (P. 216) } \\
\text { "To grow academically as well as } \\
\text { personally" (P. 232) }\end{array}$ \\
\hline
\end{tabular}




\subsection{Data Set 3: 'Please list the characteristics of a student who is flourishing at university.'}

\subsubsection{Academic and social engagement}

Eighty-two per cent (216 valid comments) of comments in this data set made some reference to the 'flourishing student' as being academically and socially engaged with university life (see Table 3). We identified two concepts within this category. Seventy-three per cent of comments referred to 'academic engagement', including behaviours such as attending class and obtaining good grades, and intrinsic learning such as gaining knowledge. 'Social engagement' was identified as a characteristic of a flourishing student by one third (34\%) of students. This encompassed ideas such as maintaining positive relationships with staff and classmates, being friendly and outgoing, and respecting others (keywords included relationship, sociable, communication, interacts).

Table3. Concept and category codebook for Data Set 3

\begin{tabular}{|c|c|c|c|}
\hline Category & Overview & Keyword examples & Text examples \\
\hline $\begin{array}{l}3.3 .1 \\
\text { Academic and } \\
\text { social } \\
\text { engagement } \\
\text { Success }\end{array}$ & $\begin{array}{l}\text { Mentions of being } \\
\text { successful or } \\
\text { succeeding at } \\
\text { university. } \\
\text { Mentions of being } \\
\text { socially active at } \\
\text { university or } \\
\text { engaging with } \\
\text { others at university. }\end{array}$ & $\begin{array}{l}\text { study } \\
\text { grades } \\
\text { attend } \\
\text { class } \\
\text { lecture } \\
\text { good } \\
\text { exams } \\
\text { sociable } \\
\text { students } \\
\text { relationships } \\
\text { participate } \\
\text { interact } \\
\text { friendly } \\
\text { respect } \\
\text { communication }\end{array}$ & $\begin{array}{l}\text { "...gaining good/great marks, getting coursework in } \\
\text { on time." (P. 4) } \\
\text { "Passing all examinations and coursework; } \\
\text { participates in social activities." (P. 14) } \\
\text { "Attend the class regularly...enjoy the time in } \\
\text { uni/the time attend the class; be part of the } \\
\text { communities offered by university." (P. 24) } \\
\text { "Better grades; bigger network of social friends \& } \\
\text { colleague[s]; someone who is more vocal in } \\
\text { lectures..." (P. 33) } \\
\text { "Absorbed in coursework/study." (P. 46) } \\
\text { "Socially supported." (P. 54) }\end{array}$ \\
\hline 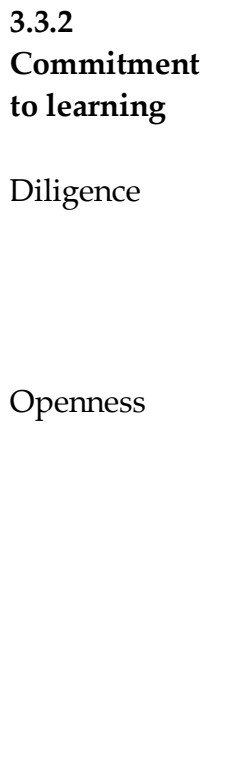 & $\begin{array}{l}\text { Mentions of being } \\
\text { diligent, serious } \\
\text { about studies and } \\
\text { committed. } \\
\text { Mentions of being } \\
\text { focused/organised. } \\
\text { Mentions of being } \\
\text { open to learning, } \\
\text { curious, willing and } \\
\text { intrinsically } \\
\text { receptive to new } \\
\text { ideas and } \\
\text { knowledge. }\end{array}$ & $\begin{array}{l}\text { diligent } \\
\text { discipline } \\
\text { focus } \\
\text { work } \\
\text { realistic } \\
\text { serious } \\
\text { willing } \\
\text { open } \\
\text { curious } \\
\text { inquisitive } \\
\text { learning } \\
\text { creative } \\
\text { questioning }\end{array}$ & $\begin{array}{l}\text { “Hard working; determined; focus..." (P. 6) } \\
\text { “Someone who takes her [sic] degree seriously.” (P. } \\
\text { 28) } \\
\text { “...work properly." (P. 80) } \\
\text { “...determined, clever.” (P. 89) } \\
\text { “...openness, willing to learn/ask questions...” (P. } \\
\text { 233) } \\
\text { “...openness to experience..." (P. 232) } \\
\text { “...curious, interested...not afraid to look stupid } \\
\text { asking questions.” (P. 236) } \\
\text { “...enthusiastic in their particular course." (P. 173) }\end{array}$ \\
\hline
\end{tabular}


Table3. Concept and category codebook for Data Set 3 (Cont.)

\begin{tabular}{|c|c|c|c|}
\hline Category & Overview & Keyword examples & Text examples \\
\hline $\begin{array}{l}\text { 3.3.3 Vitality } \\
\text { and personal } \\
\text { growth }\end{array}$ & $\begin{array}{l}\text { Mentions of being } \\
\text { engaged with life or } \\
\text { specific life } \\
\text { domains. Mentions } \\
\text { of being confident } \\
\text { and self-motivated. } \\
\text { Mentions of } \\
\text { progress, } \\
\text { improving, getting } \\
\text { better. }\end{array}$ & $\begin{array}{l}\text { confident } \\
\text { motivated } \\
\text { engaged } \\
\text { happy } \\
\text { optimistic } \\
\text { progress } \\
\text { develop } \\
\text { grow } \\
\text { thriving } \\
\text { excel } \\
\text { potential } \\
\text { better }\end{array}$ & $\begin{array}{l}\text { “Happy, motivated, engaged." (P. 1) } \\
\text { "Self-motivators." (P. 2) } \\
\text { "Happy to be there." (P. 12) } \\
\text { “Confidence, happy..." (P. 39) } \\
\text { “...engages in curriculum activities." (P. 88) } \\
\text { “...student who always thinking to make study } \\
\text { better." (P. 152) } \\
\text { "Personally satisfied and developing..." (P. 237) } \\
\text { “...someone that does their best to grow and } \\
\text { flourish..." (P. 28) }\end{array}$ \\
\hline
\end{tabular}

\subsubsection{Commitment to learning}

Our coding process identified $61 \%$ of comments that made reference to a series of desirable student characteristics regarding commitment to learning (216 valid comments; see Table 3). These appeared as both intrinsic characteristics and overt behaviours. We identified two interrelated concepts within this category. 'Diligence' was mentioned by $47 \%$ of students. This concept emerged from a group of keywords relating to 'introverted' or 'closed' ideas (e.g. intelligent, determined, disciplined, hard worker) which characterised flourishing students as serious, studious and generally diligent in their academic work. Twenty-seven per cent of comments made reference to 'openness to learning', our second concept. This was conceived as a group of ideas relating to willingness and enthusiasm for learning ('willing to learn' was a recurring comment), interest, curiosity and inquisitiveness.

\subsubsection{Vitality and personal growth}

Forty-eight per cent of comments referred to vitality and personal growth (216 valid comments; Table 3). This category strongly resembled the ideas about self-actualisation and wellbeing that emerged in Data Sets 1 and 2. Within the category, however, a larger proportion (37\%) of comments made reference to the concept of 'vitality', which included a range of ideas relating to self-motivation, confidence, optimism and engagement with academic studies and university life. Although the concept also included enjoyment, it was labelled 'vitality' due to greater emphasis (reference frequency) on self-motivation and confidence than on positive affect (enjoyment, contentment, etc.). Eighteen per cent of comments referred to personal growth (improve, develop, progress) in contexts similar to self-actualisation in Data Sets 1 and 2.

\subsection{Data Set 4: 'Please list the characteristics of a student who is not flourishing at university.'}

\subsubsection{Negation and lacking}

Fifty-seven per cent of comments used keywords such as no, not, and lacking when commenting on the 'non-flourishing' student (214 valid comments; see Table 4). These were consistently used before keywords with positive connotations, suggesting that non-flourishing may be at least partially the 'opposite' of flourishing. Moreover, the comments in this category appeared 
to construct the 'non-flourishing' student as one who is simply not flourishing or who does not possess the characteristics of the 'flourishing' student.

Table 4. Concept and category codebook for Data Set 4

\begin{tabular}{|c|c|c|c|}
\hline Category & Overview & $\begin{array}{l}\text { Keyword } \\
\text { examples }\end{array}$ & Text examples \\
\hline $\begin{array}{l}\text { 3.4.1 Negation } \\
\text { and lacking }\end{array}$ & $\begin{array}{l}\text { Mentions of negativity, 'not' } \\
\text { doing/being. Mentions of } \\
\text { lacking particular behaviours } \\
\text { or attributes. }\end{array}$ & $\begin{array}{l}\text { no } \\
\text { not } \\
\text { negative } \\
\text { lack }\end{array}$ & $\begin{array}{l}\text { "Not very disciplined." (P. 5) } \\
\text { "Not motivated, not willing..." (P. 6) } \\
\text { “Lack of confidence..." (P. 34) } \\
\text { “...don't care about study." (P. 83) } \\
\text { “...non participation at classes." (P. } \\
\text { 153) }\end{array}$ \\
\hline $\begin{array}{l}3.4 .2 \\
\text { Disengagement } \\
\text { from academic } \\
\text { work and } \\
\text { learning }\end{array}$ & $\begin{array}{l}\text { Mentions of } \\
\text { negative/undesirable student } \\
\text { behaviours, especially failure } \\
\text { to engage with traditional } \\
\text { academic commitments such } \\
\text { as lectures, etc. Mentions of } \\
\text { unwillingness to try or to put } \\
\text { in effort to learn. }\end{array}$ & $\begin{array}{l}\text { late } \\
\text { not on time } \\
\text { absent } \\
\text { poor } \\
\text { grades } \\
\text { study } \\
\text { deadline } \\
\text { attend }\end{array}$ & $\begin{array}{l}\text { "Does not attend class and pass } \\
\text { examinations and assignments..." (P. } \\
\text { 14) } \\
\text { "Someone struggling to meet } \\
\text { deadlines..." (P. 18) } \\
\text { "A student that struggles to } \\
\text { understand elements of the courses } \\
\text { and fails to do sufficient background } \\
\text { study..." (P. 35) } \\
\text { "Gets bad grades or sometimes } \\
\text { average scores or below average..." (P. } \\
92)\end{array}$ \\
\hline $\begin{array}{l}\text { 3.4.3 Laziness, } \\
\text { struggle and } \\
\text { social } \\
\text { withdrawal }\end{array}$ & $\begin{array}{l}\text { Mentions of being lazy in } \\
\text { relation to academic work. } \\
\text { Mentions of feeling lost and } \\
\text { struggling with work/learning. } \\
\text { Mentions of being or feeling } \\
\text { socially isolated. Mentions of } \\
\text { negative affect. }\end{array}$ & $\begin{array}{l}\text { lazy } \\
\text { lost } \\
\text { struggle } \\
\text { depressed } \\
\text { withdrawn } \\
\text { stress } \\
\text { disorganised } \\
\text { confused } \\
\text { mess } \\
\text { shy } \\
\text { hopeless } \\
\text { pessimist } \\
\text { sad } \\
\text { recluse }\end{array}$ & $\begin{array}{l}\text { "Pessimistic...helpless..." (P. 19) } \\
\text { "Sad, discontentment..." (P. 29) } \\
\text { “Grumpy, isolated." (P. 102) } \\
\text { “Laziness, procrastination..." (P. 132) } \\
\text { “Disorganised, miserable, sad, } \\
\text { lackadaisical." (P. 156) } \\
\text { “A recluse..." (P. 156) } \\
\text { "Lazy, disorganised..." (P. 249) }\end{array}$ \\
\hline $\begin{array}{l}\text { 3.4.4 Absence of } \\
\text { striving and } \\
\text { vitality }\end{array}$ & $\begin{array}{l}\text { Mentions of what 'not } \\
\text { flourishing' is not, i.e. } \\
\text { references to keywords used in } \\
\text { Question } 3 \text { comments, } \\
\text { commonly qualified with 'no', } \\
\text { 'not' etc. Mentions of lacking } \\
\text { motivation, interest, or } \\
\text { something to hope or strive } \\
\text { for. Mentions of not trying or } \\
\text { wanting. Mentions of being } \\
\text { the 'opposite' of flourishing. }\end{array}$ & $\begin{array}{l}\text { goal } \\
\text { aim } \\
\text { knowledge } \\
\text { motivated } \\
\text { interest } \\
\text { effort } \\
\text { success } \\
\text { confident } \\
\text { achieve } \\
\text { progress } \\
\text { improve } \\
\text { potential }\end{array}$ & $\begin{array}{l}\text { "...someone who does worse than their } \\
\text { expectations/potential...someone who } \\
\text { does not...achieve their goals." (P. 45) } \\
\text { "A student who doesn't care." (P. 47) } \\
\text { "No interest, no noticeable } \\
\text { improvement." (P. 44) } \\
\text { “...does not want to learn..." (P. 127) } \\
\text { "...not friendly and happy, not } \\
\text { interested..." (P. } 130 \\
\text { “...not confident." (P. 184) } \\
\text { “...those [who] don't have a goal..." (P. } \\
\text { 240) }\end{array}$ \\
\hline
\end{tabular}




\subsubsection{Disengagement from academic work and learning}

'Disengagement' was not a keyword used in any of the comments. We selected this as a label because virtually all comments in the category stated, or implied, that students' failure to engage with academic commitments came about from an intrinsic lack of interest, effort or willingness rather than external factors, as seen in Table 4. Fifty-three per cent of comments characterised a non-flourishing student as being behaviourally disengaged from traditional academic commitments such as attending lectures and completing examinations and coursework (214 valid comments). Our sample expressed this disengagement as skipping lectures, failing to meet deadlines, obtaining poor grades, or generally failing to be involved with academic work and learning.

\subsubsection{Laziness, struggle, and social withdrawal}

Fifty-two per cent of comments mentioned laziness, struggle, and social withdrawal (214 valid comments; Table 4). This category encompassed a range of keywords (predominantly adjectives) characterising non-flourishing as being lazy in relation to doing academic work, struggling to understand subjects, and general negative affect (e.g. unhappy, depressed, sad) in relation to being socially withdrawn or reclusive. In particular, lazy (laziness) was the most frequently mentioned keyword, cited by one quarter (25\%) of the sample. This category portrayed the non-flourishing student as possessing a range of undesirable personal qualities, both as a student (lazy, disorganised, procrastinate, bored) and in socio-emotional terms (shy, hopeless, isolated, discouraged).

\subsubsection{Absence of striving and vitality}

Forty-two per cent of comments explained non-flourishing in terms of what it is not (214 valid comments). This category brought together most keywords appearing in categories from our first three data sets, particularly 'self-actualisation' and 'success' categories (e.g. goal, interest, willing, confident, achieve, progress, etc.), summarised in Table 4. Here, the non-flourishing student was characterised as either lacking personal goals or failing to achieve them, being uninterested or unwilling in relation to academic learning, and lacking motivation to learn, improve, or progress. Keywords in this category almost always appeared with Negation and Lacking keywords (no, not, lack) to denote a general absence of 'flourishing' behaviours and characteristics.

\subsection{Contradictions and variations}

Our data sets included three minorities of comments that could not be coded into the emergent categories, yet we felt these were important in answering our research questions. The first of these concerned the idea of extraversion/introversion in flourishing. Comments mentioning the social aspects of flourishing overwhelmingly mentioned extraversion (making friends, participating in activities, asking questions) and social engagement as constituting the flourishing student. However, two comments in Data Set 3 identified flourishing students as inherently introverted. For example, one participant wrote "...nerdy, unsociable perhaps...loners, people who prefer books to people." (Participant 2, Data Set 3). This is in contradiction to much of the current literature, which tends to support a characterisation of flourishing emphasising social participation and engagement (Keyes, 2002). In this case, the relationship of flourishing 
with introversion may have some relation to balancing academic work with social life, wherein flourishing to a high degree in academia may be at the detriment of social life.

A second minority of comments (nine comments in Data Sets 1 and 2) mentioned collective flourishing as opposed to individual flourishing. These made reference to larger groups such as the student body, communities, or society when defining flourishing. Participants defining flourishing in collective terms also tended to define flourishing at university in collective terms. One participant wrote:

The word flourishing means a steady boom in a society or community. It also means a steady consistent rise of slope in a graphical manner. Flourishing therefore is a steady consistent rise of a particular thing or development in society. (Participant 49, Data Set 2).

The same participant continued, "To flourish [at] university... is a steady consisten[cy] of student attendance in the university community with the aim of achieving positive result...in the university community or society." Comments referring to collective flourishing align with Aristotelian and Marxist perspectives, which posited that flourishing can occur only in societies in which citizens act in accordance with their true (virtuous) nature and not in individuals alone (Leopold, 2007).

A final issue concerned whether flourishing is determined intrinsically or extrinsically. The majority of our data referred to intrinsic determination, or the idea that flourishing is determined by personal determination, deliberation, or effort. However, five comments in Data Sets 1 and 2 stated flourishing is enabled by extrinsic factors, such as social support or other favourable conditions [e.g. "To excel and do well in something due to favourable conditions." (Participant 179, Data Set 1)]. This contradiction remains largely open given that flourishing seems likely to be a balance of both eudaimonic (i.e. intrinsically determined) and hedonic (extrinsically determined) wellbeing.

\section{Discussion}

Major ideas about 'flourishing' in the present data sets emerged as self-actualisation and success. This finding may lend inductively derived support for the 2-component structure of flourishing proposed by Vittersø (2009). According to this model, individuals flourish in a selfperpetuating positive cycle of achievement (success) and striving (for the realisation of potential, or of self-actualising experiences). However, the emergence of additional categories in our 'flourishing' data set, such as positive affect, indicate that flourishing is a multidimensional construct as far as it was defined by the present sample. Findings of the present study largely map onto the PERMA model of flourishing proposed by Seligman (2011). Categories such as positive affect, engagement (academic; discussed below), engagement (social), and success readily correspond with the model's positive emotions, engagement, relationships and achievement facets, respectively (see Figure 3). 
Figure 3. The correspondence of categories emerging from the present data sets to Seligman's (2011) PERMA model of flourishing

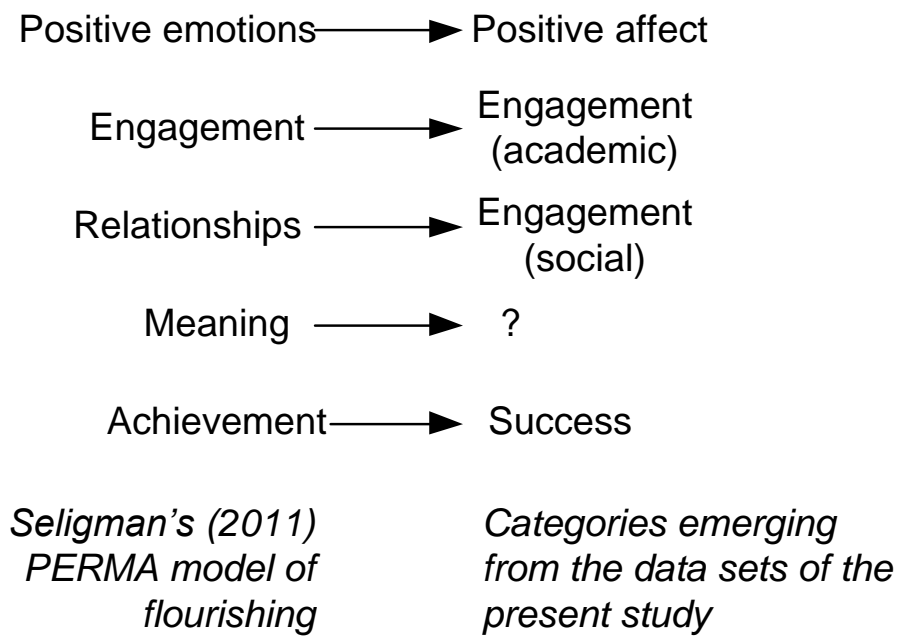

Although the role of 'meaning' in the present data is less clearly defined, the emergence of conceptual categories covering a range of cognitive, psychological and behavioural domains of wellbeing lends itself to a multidimensional conceptualisation of flourishing which incorporates both empirically and inductively derived components.

The emergence of engagement (both academic and social) in our 'flourishing at university' data poses at least two questions regarding the construction of 'flourishing' in HE settings. Firstly, it is unclear whether the types of engagement (both behavioural and attitudinal) mentioned by students in our sample constitute a facet of flourishing unique to a HE setting, or are instead a type of flourishing in themselves. Reschly and colleagues (Reschly, Huebner, Appleton, \& Antaramian, 2008) have previously found associations between positive emotions and engagement in adolescents within a secondary school setting. This association was partially mediated by adaptive coping, supporting Fredrickson's (2004, 2005, 2009) broadenand-build theory of positive emotions. The association between 'engagement' (Appleton, Christenson, Kim, \& Reschly, 2006) and what could be considered a state of flourishing (the 'upward spirals' of Fredrickson's theory) indicate that engagement is a distinct phenomenon from flourishing. However, more research is needed to investigate the dynamics of the engagement-flourishing relationship, particularly in HE settings where the role of flourishing is less clear than in compulsory-level education (e.g. Gilman, Huebner, \& Furlong, 2009).

The second question posed by the emergence of 'engagement' in our data concerns which sub-types of engagement are most necessary to facilitate flourishing in a HE setting. Participants in the present sample commonly mentioned behavioural (e.g. attending class, meeting coursework deadlines) and psychological (e.g. interacting with peers, participating in social learning activities) sub-types in our 'academic and social engagement' category, although the emergence of additional categories such as academic 'success' and 'commitment to learning', which indicated achievement and positive attitudinal orientation towards studies, suggest that all four types of engagement, including academic and cognitive (Appleton et al., 2006), are relevant to students' potential to flourish in Higher Education. Previous studies have shown a general decrease in engagement-related factors (such as curiosity or interest in 
learning) in adolescents transitioning from primary to secondary school settings (reported in Shah \& Marks, 2004), suggesting that some young people may go on to arrive in HE with low levels of engagement. It is less clear how engagement may change for students of other age groups who do not come to HE directly from compulsory-level education. Therefore, the issue of engagement, particularly the prevalence of its sub-types and their relative importance for flourishing, is a key domain for future research in the engagement-flourishing link to explore.

The structure of characterisations of the 'flourishing' and 'non-flourishing' student in our latter two data sets resemble Keyes' (2002) mental health continuum, which proposes flourishing is a state of complete positive mental health as opposed to languishing, a state of ineffective functioning insufficiently severe to be diagnosed as mental illness. In the present sample, students' understandings of the 'flourishing' student tended to centre on academic and behavioural engagement and on positive attitudes towards learning (interest, curiosity, focus, diligence). Conversely, the 'non-flourishing' student was generally constructed as behaviourally and academically disengaged from studies and lacking all or most of the characteristics possessed by the 'flourishing' student. Although 'non-flourishing' necessarily entailed a general absence of the characteristics of 'flourishing', it appeared to have additional characteristics (emerging in the 'laziness, struggle, and social withdrawal' category) that made it distinct from merely the opposite of 'flourishing' for our sample. This suggests that not to flourish in HE is not merely to lack a state of flourishing, but to possess a range of ineffective functioning characteristics resembling a state of 'languishing' (Keyes, 2002), including behavioural characteristics such as being distracted from academic work by other activities and attitudinal qualities such as a 'lazy' outlook on learning. Related studies have found that students often attribute academic outcomes (such as success or 'unsuccess') to intrinsically determined factors such as self-motivation or laziness (Lebedina-Manzoni, 2004) and that student wellbeing parameters such as flow are statistically associated with low levels of such intrinsic factors as motivation (Lee, 2005) and student effort (Killen, 1994). The area of 'flourishing' and 'non-flourishing' students in HE settings is one that merits further research, particularly with respect to assessing the way 'flourishing' and 'non-flourishing' student profiles relate to each other and whether 'non-flourishing' may be conceptualised as distinct from the 'opposite' of flourishing on the basis of characteristics such as laziness and disengagement.

In addition to addressing the above questions raised by this study, future research in the area of flourishing in Higher Education may develop the student conceptualisation of 'flourishing' further by using data from a wider sample of students. The use of a sample composed of students enrolled only in post-1992 (former polytechnic) universities creates some difficulty in generalising our findings to the wider British HE sector. For example, differences in academic culture and greater emphases on either teaching or research in pre-1992 institutions ('traditional' universities) may influence the conceptualisation of 'flourishing' in students within such institutions (e.g. Russell Group, 1994 Group, University Alliance, and million+ institutions). Greater student success in terms of research output and publication at research-oriented institutions (Cooper \& Turpin, 2007) may be implicated in different conceptualisations of what constitutes flourishing at university and flourishing students. Flourishing may also be conceptualised differently among undergraduate students compared with postgraduate students, and among postgraduate taught students compared with postgraduate research students, given the different emphases that are placed on learning set 
curricula and creating original knowledge. The conceptualisation of 'flourishing' among academics or tutors in the HE sector may also carry differences from that among the student body, for example in terms of engagement or participation (Fritschner, 2000). The construction of flourishing among these distinct groups may be another area of future exploration.

In the context of Higher Education, extrinsically measured success (e.g. passing exams) continues to form the traditional (formative) basis of academic work and progress. However, the emergence of factors such as self-actualisation, engagement, and positive affect as important facets of flourishing for students may call for a new focus on the purposes and valued outcomes of HE that goes beyond extrinsically measured success and a 'value for money' orientation. Although flourishing is a complex phenomenon that cannot be measured by any singular means, developing a HE culture in which flourishing is recognised as necessary in both the means and ends of education may be a way forward in ensuring students' potential to flourish is preserved and facilitated in the present period of economic transition.

\section{Authors}

Nesrin Gokcen

University of East London

n.gokcen@uel.ac.uk

Kate Hefferon

University of East London

k.hefferon@uel.ac.uk

Elizabeth Attree

University of East London

e.a.attree@uel.ac.uk

\section{Publishing Timeline}

Received 8 December 2011

Accepted 14 December 2011

Published 29 April 2012

\section{References}

Appleton, J. J., Christenson, S. L., Kim, D., \& Reschly, A. (2006). Measuring cognitive and psychological engagement: Validation of the Student Engagement Instrument. Journal of School Psychology, 44, 427445. http://dx.doi.org/10.1016/j.jsp.2006.04.002

Aristotle. (350 BC/2000). Nicomachean ethics. Trans. R. Crisp. Cambridge: Cambridge University Press.

Bauer, J. J. \& Perciful, M. S. (2009). Constructivism. In S. J. Lopez (Ed.), Encyclopedia of positive psychology (vol. 1, pp. 226-231). Chichester, West Sussex: Wiley-Blackwell.

Browne, J., Barber, M., Coyle, D., Eastwood, D., King, J., Naik, R. et al. (2010). Securing a sustainable future for higher education: An independent review of higher education funding $\mathcal{E}$ student finance. London. http://webarchive.nationalarchives.gov.uk/+/hereview.independent.gov.uk/hereview//report/

Business in the Community. (2010). Race into higher education: Today's diverse generation into tomorrow's workforce. London. http://www.bitcdiversity.org.uk/research/rfo race in higher education/index.html

Catalino, L. I. \& Fredrickson, B. L. (2011). A Tuesday in the life of a flourisher: The role of positive emotional reactivity in optimal mental health. Emotion, 11(4), 938-950.

http://dx.doi.org/10.1037/a0024889 
Cooper, M. \& Turpin, G. (2007). Clinical psychology trainees' research productivity and publications: An initial survey and contributing factors. Clinical Psychology \& Psychotherapy, 14(1), 54-62. http://dx.doi.org/10.1002/cpp.513

Deci, E. L. \& Ryan, R. M. (1985). Intrinsic motivation and self-determination in human behavior. New York: Plenum Press.

Deci, E. L. \& Ryan, R. M. (2008a). Facilitating optimal motivation and psychological well-being across life's domains. Canadian Psychology, 49, 14-23. http://dx.doi.org/10.1037/0708-5591.49.1.14

Deci, E. L. \& Ryan, R. M. (2008b). Self-determination theory: A macrotheory of human motivation, development, and health. Canadian Psychology, 49, 182-185. http://dx.doi.org/10.1037/a0012801

Delucchi, M. \& Korgen, K. (2002). "We're the customer - we pay the tuition": Student consumerism among undergraduate sociology majors. Teaching Sociology, 30(1), 100-107. http://dx.doi.org/10.2307/3211524

Diener, E., Wirtz, D., Tov, W., Kim-Prieto, C., Choi, D-W., Oishi, S., \& Biswas-Diener, R. (2010). New well-being measures: Short scales to assess flourishing and positive and negative feelings. Social Indicators Research, 97, 143-145. http://dx.doi.org/10.1007/s11205-009-9493-y

Fairchild, E., Crage, S., Martin, J., Pescosolido, B., Smith, R., Kurz, L. et al. (2007). Measuring student consumerism in higher education. (Unpublished manuscript). Indiana University, Bloomington, IN.

Flourish. (1964). In E. McIntosh (Ed.), The Concise Oxford Dictionary (p. 467, $5^{\text {th }}$ ed.). Oxford: Clarendon Press.

Forgeard, M. J. C., Jayawickreme, E., Kern, M. L., \& Seligman, M. E. P. (2011). Doing the right thing: Measuring wellbeing for public policy. International Journal of Wellbeing, 1(1), 79-106.

Fredrickson, B. L. (2003). Positive emotions and upward spirals in organizational settings. In K. Cameron, J. Dutton and R. Quinn (Eds.) Positive Organizational Scholarship (pp. 163-175). San Francisco: Berret-Koehler.

Fredrickson, B. L. (2004). The broaden-and-build theory of positive emotions. Philosophical Transactions of the Royal Society B, 359, 1367-1377. http://dx.doi.org/10.1098/rstb.2004.1512

Fredrickson, B. L. (2005). The broaden-and-build theory of positive emotions. In F. A. Huppert, N. Baylis, \& B. Keverne (Eds.) The Science of Well-Being (pp. 217-238). New York: Oxford University Press.

Fredrickson, B. L. (2009). Positivity: Groundbreaking research reveals how to embrace the hidden strength of positive emotions, overcome negativity, and thrive. New York: Crown.

Fritschner, L. M. (2000). Inside the undergraduate college classroom: Faculty and students differ on the meaning of participation. The Journal of Higher Education, 71(3), 342-362. http://dx.doi.org/10.2307/2649294

Gilman, R., Huebner, E. S., \& Furlong, M. J. (Eds.) (2009). Handbook of positive psychology in schools. New York: Routledge.

Gottman, J. M. (1994). What predicts divorce? The relationship between marital processes and marital outcomes. Hillsdale, NJ: Erlbaum.

Hill, T. E. (1999). Happiness and human flourishing in Kant's ethics. Social Philosophy and Policy, 16(1), 143-175. http://dx.doi.org/10.1017/S0265052500002284

Hsieh, H-F. \& Shannon, S. E. (2005). Three approaches to qualitative content analysis. Qualitative Health Research, 15, 1277-1288. http://dx.doi.org/10.1177/1049732305276687

Huppert, F. A. \& So, T. T. C. (2009). What percentage of people in Europe are flourishing and what characterises them? Measuring subjective well-being: An opportunity for NSOs? OECD/ISQOLS meeting, Florence, Italy, 23-24 July.

Huppert, F. A. \& So, T. T. C. (2011). Flourishing across Europe: Application of a new conceptual framework for defining well-being. Social Indicators Research.

Kaye, T. S., Bickel, R. D., \& Birtwistle, T. (2006). Criticizing the image of the student as consumer: Examining legal trends and administrative responses in the US and UK 1. Education and the Law, 18(2-3), 85-129. http://dx.doi.org/10.1080/09539960600919779 
Keyes, C. L. M. (2002). The mental health continuum: From languishing to flourishing in life. Journal of Health and Behavior Research, 43, 207-222. http://dx.doi.org/10.2307/3090197

Keyes, C. L. M. (2005). Mental health and/or mental illness? Investigating axioms of the complete state model of health. Journal of Consulting and Clinical Psychology, 73, 539-548. http://dx.doi.org/10.1037/0022-006X.73.3.539

Keyes, C. L. M. (2006). Mental health in adolescence: Is America's youth flourishing? American Journal of Orthopsychiatry, 76, 395-402. http://dx.doi.org/10.1037/0002-9432.76.3.395

Keyes, C. L. M. (2007a). Promoting and protecting mental health as flourishing: A complementary strategy for improving national mental health. American Psychologist, 62, 95-108. http://dx.doi.org/10.1037/0003-066X.62.2.95

Keyes, C. L. M. (2007b). Towards a mentally flourishing society: Mental health promotion, not cure. Journal of Public Mental Health, 6, 4-7. http://dx.doi.org/10.1108/17465729200700009

Killen, R. (1994). Differences between students' and lecturers' perceptions of factors influencing students' academic success at university. Higher Education Research and Development, 13, 199-212. http://dx.doi.org/10.1080/0729436940130210

Krippendorf, K. (2004). Content analysis: An introduction to its methodology. Thousand Oaks, CA: Sage.

Lebedina-Manzoni, M. (2004). To what students attribute their academic success and unsuccess. Education, 124(4), 699-708.

Lee, E. (2005). The relationship of motivation and flow experience to academic procrastination in university students. Journal of Genetic Psychology, 166, 5-14. http://dx.doi.org/10.3200/GNTP.166.1.5-15

Leopold, D. (2007). The young Karl Marx: German philosophy, modern politics, and human flourishing. Cambridge: Cambridge University Press. http://dx.doi.org/10.1017/CBO9780511490606

Losada, M. (1999). The complex dynamics of high performance teams. Mathematical and Computer Modelling, 30(9-10), 179-192. http://dx.doi.org/10.1016/S0895-7177(99)00189-2

Losada, M. \& Heaphy, E. (2004). The role of positivity and connectivity in the performance of business teams: A nonlinear dynamics model. American Behavioural Scientist, 47(6), 740-765. http://dx.doi.org/10.1177/0002764203260208

Marx, K. (1959/1988). The economic and philosophic manuscripts of 1844. Trans. M. Milligan. Amherst, NY: Prometheus Books.

Miller, P. J. \& Hoogstra, L. (1992). Language as tool in the socialization and apprehension of cultural meanings. In T. Schwartz, G. White \& C. Lutz (Eds.), New directions in psychological anthropology (pp. 83-101). New York: Cambridge University Press.

Naidoo, R. \& Jamieson, I. M. (2005). Empowering participants or corroding learning? Towards a research agenda on the impact of student consumerism in higher education. Journal of Education Policy, 20(3), 267-281. http://dx.doi.org/10.1080/02680930500108585

Reschly, A. L., Huebner, E. S., Appleton, J. J., \& Antaramian, S. (2008). Engagement as flourishing: The contribution of positive emotions and coping to adolescents' engagement at school and with learning. Psychology in the Schools, 45(5), 419-431. http://dx.doi.org/10.1002/pits.20306

Ryan, R. M., Huta, V., \& Deci, E. L. (2008). Living well: A self-determination theory perspective on eudaimonia. Journal of Happiness Studies, 9, 139-170. http://dx.doi.org/10.1007/s10902-006-9023-4

Ryff, C. D. (1989). Happiness is everything, or is it? Explorations on the meaning of well-being. Journal of Personality and Social Psychology, 57(6), 1069-1081. http://dx.doi.org/10.1037/0022-3514.57.6.1069

Ryff, C. D. \& Singer, B. H. (2006). Best news yet on the six-factor model of well-being. Social Science Research, 35, 1103-1119.

Seligman, M. E. P. (1999). The president's address. American Psychologist, 54, 559-562.

Seligman, M. E. P. (2002). Authentic happiness: Using the new positive psychology to realize your potential for lasting fulfilment. New York: Free Press.

Seligman, M. E. P. (2011). Flourish: A visionary new understanding of happiness and well-being. New York: Free Press. 
Shah, H. \& Marks, N. (2004). A well-being manifesto for a flourishing society. London: New Economics Foundation.

Vittersø, J. (2009). Positive psychology is about flourishing, but what is flourishing about? Invited paper presented at the First World Congress on Positive Psychology, Philadelphia, PA, 18-21 June.

Vygotsky, L. S. (1986). Thought and language. Cambridge, MA: MIT Press. 


\section{Appendix A}

Study Questionnaire

\begin{tabular}{|l|l|}
\hline Age: & Gender: MALE / FEMALE \\
\hline Course: & Mode of study: FULL TIME / PART TIME \\
\hline
\end{tabular}

Instructions: Please write down your answers to the items below. There are no right or wrong answers.

What does 'flourishing' mean?

What does it mean to flourish at university?

Please list the characteristics of a student who is flourishing at university.

Please list the characteristics of a student who is not flourishing at university. 